DOCTRINA

\title{
Panorama de la discusión sobre el derecho al olvido en Brasil
}

\author{
Overview of the discussion about the right to forgetfulness in Brazil
}

\section{Thamiris Schiavinoto Guimarães (iD}

Abogada, Brasil

\begin{abstract}
RESUMEN El objetivo de este artículo es analizar la recepción y aplicación del derecho al olvido en Brasil. Se hará un análisis de la colisión de derechos fundamentales, con base en el análisis de la doctrina nacional y de la jurisprudencia constitucional emanada del Supremo Tribunal Federal, del Superior Tribunal de Justicia, del caso que dio origen a la discusión del derecho al olvido y de casos recientes discutidos en tribunales extranjeros sobre el derecho a la privacidad, la vida privada y el derecho a la inviolabilidad de todas las formas de comunicación privada.
\end{abstract}

PALABRAS CLAVE Derechos de personalidad, derecho al olvido, intimidad, vida privada, jurisprudencia.

ABSTRACT The objective of this article is to analyze the reception and application of the right to be forgotten in Brazil. An analysis of the collision of fundamental rights will be made, based on the analysis of national doctrine and constitutional jurisprudence emanating from the Supreme Federal Court of the Superior Court of Justice, of the case that gave rise to the discussion of the right to neglect and recent cases discussed in foreign courts about the right to privacy, privacy and the right to the inviolability of all forms of private communication.

KEYWORDS Personality rights, right to forgetfulness, intimacy, private life, jurisprudence.

\section{Introducción}

En una sociedad movida por la hiperinformación, que está directamente relacionada con el desarrollo en masa de la tecnología, donde las informaciones se difunden mediante diversos vehículos de comunicación, beneficiosos o injuriosos, surge el conflicto entre el derecho a la información en sentido amplio y el derecho a la personalidad. 
Mientras el primero es un factor predominante en la divulgación de noticias, el segundo busca tutelar la protección individual como uno de los aspectos más intrínsecos del ser humano.

Por un lado, están los que defienden el derecho a la intimidad previsto en la Constitución de la República Federal de Brasil: a tener sus vidas resguardadas de la curiosidad ajena, aunque tengan algún momento notorio en su trayectoria; por otro, los que reivindican el derecho, también presente en el texto constitucional, a la libertad de expresión, y afirman que la actual regulación se expresa en sentido contrario, pues no solo es inconstitucional, sino que también actualiza la censura.

En este sentido, en este artículo se discutirá inicialmente la aparición de los derechos de la personalidad en la segunda mitad del siglo XX y la consagración de lo que vendrá a ser la dignidad de la persona humana en la Declaración de los Derechos Humanos de 1948, así como cada uno de los derechos de la personalidad. Posteriormente se tratará del derecho al olvido en sí mismo, con la debida limitación conceptual y de sus fundamentos, junto con las consideraciones pertinentes al derecho a la información, a la luz de la Constitución Federal de 1988. Más adelante se discutirá acerca de la intimidad, la honra y la vida privada como límites a la libertad de expresión. En la cuarta y última parte se abordarán los casos concretos, desde el primer caso en que se discutió el derecho al olvido en Europa, a los casos brasileños de la jurisprudencia del Tribunal Superior de Justicia y el Supremo Tribunal Federal y los recientes casos en Chile y en Europa.

Se utilizó el método hipotético deductivo, teniendo como instrumentos esenciales para la consecución del objetivo presentado la doctrina y la jurisprudencia.

\section{Derechos de la personalidad}

En Leviatán, Hobbes asoció la figura del monstruo bíblico, poderoso e invencible, con la figura del Estado, aquel cuya presencia era esencial para controlar la natural tendencia de los hombres al conflicto (Hobbes, 2008). Cerca de cien años después de su publicación, los franceses salieron a la calle para enfrentar el Absolutismo y marcaron, en 1789, el inicio de la Edad Moderna y, por lo tanto, del derecho moderno, que nació bajo la influencia del liberalismo económico.

El hombre se vio libre del Estado y la dicotomía entre derecho privado y derecho público daba autonomía para llevar a cabo la voluntad de los particulares, que podían regir sus vidas sin la intromisión del Estado. Sin embargo, lo que se vio fue una progresiva degradación del hombre por el hombre. Principalmente a partir de la Revolución Industrial, en el siglo XIX, cuando se reivindicó la libertad individual y se mantuvo al Estado lejos de las relaciones entre particulares (Tepedino, Barboza y Moraes, 2007: 1-22).

Los juristas no tardaron en percibir que la libertad no lo era todo. Al crear una especie de actuación a salvo de cualquier interferencia estatal, el liberalismo jurídico acabó por canalizar la sumisión impuesta por las fuerzas económicas. De esta forma, era su- 
ficiente proteger al hombre del Estado y de sus semejantes. Era necesario evitar que el propio hombre, ante las necesidades más urgentes, abdicase de sus derechos esenciales.

En este contexto, en la segunda mitad del siglo XIX surgieron las primeras construcciones en torno a los derechos de la personalidad. Eran, ya entonces, derechos considerados esenciales a la condición humana, derechos sin los cuales «todo el resto de los derechos subjetivos perderían cualquier interés para el individuo, al punto de llegar a decir que, si no existiesen, la persona no sería más persona» (Cupis, 1950: 18-19). ${ }^{1}$ Sin embargo, las críticas a los derechos de la personalidad minaron su desarrollo: el Código Civil alemán de 1896 y el Código Civil brasileño de 1916 dejaron de abordarlos.

Aconteció que dos grandes guerras devastaron el mundo. Los horrores del holocausto nazi y la efectiva utilización de las bombas atómicas fueron algunos de los terrores de que el mundo fue testigo en aquel período; por todos lados surgieron llamados a implementar un nuevo orden de valores, capaz de proteger la condición humana de su propia vulnerabilidad. En 1948, la Declaración Universal de los Derechos Humanos, aprobada por la Asamblea General de las Naciones Unidas, expresó que «la libertad, la justicia y la paz en el mundo tienen por base el reconocimiento de la dignidad intrínseca y de los derechos iguales e inalienables de todos los miembros de la familia humana» (Organización de las Naciones Unidas, 1948: Preámbulo). Así, quedó consagrada la dignidad de la persona humana, adoptada por la Constitución de la República Federal de Brasil de 1988, que alcanzó al derecho privado dando énfasis a los derechos de personalidad.

La Constitución de la República Federal de Brasil trata los derechos de la personalidad porque sus objetivos son también los de los derechos y las garantías fundamentales, que revelan ciertos aspectos de derechos indisponibles y protegidos de forma especial, con una característica de oponibilidad erga omnes. Se basan en el principio de la dignidad de la persona humana. En Brasil, básicamente por vía doctrinal o judicial, las garantías constitucionales recogidas en la Constitución de 1891 y la interpretación de sus principios se incorporaron a nuestro Estado por influencia de Ruy Barbosa, quien en su lección acerca de las garantías constitucionales resaltó las diferencias entre garantías constitucionales y derechos, definiendo stricto sensu las garantías constitucionales como las «solemnidades tutelares, de que la ley circunda algunos de esos derechos contra los abusos del poder», refiriéndose a los derechos de la personalidad (Silva, 2009a: 193-194). Amancio Alcorta contribuyó a consolidar el concepto, pero sin distinguir las garantías constitucionales de las garantías individuales, concretando los derechos de la personalidad, dando contenido al requisito de Laboulaye, que refiere que no basta con conocer tales derechos, sino que también es necesario protegerlos (Silva, 2009a: 6-7, 35).

En razón de esa relación de los derechos fundamentales del individuo con la libertad de disposición y contenido individualista, es que las garantías constitucionales se han convertido en una especie de escudo de la personalidad contra las desviaciones

1. Todas las traducciones son de la autora. 
del poder del Estado. La concreción de tales garantías se ha convertido, en un cierto sentido, en algo tanto o más importante que los propios derechos contenidos en la Constitución, o por esta enunciados, pudiendo ser las garantías constitucionales garantías de la propia Constitución como garantías de los derechos subjetivos expresados u otorgados en ella.

Como afirma Pontes de Miranda:

a) En el soporte fáctico de cualquier hecho jurídico, del que surge el derecho, hay, necesariamente, alguna persona, como elemento del soporte; b) en el soporte fáctico del hecho jurídico del que surge el derecho de la personalidad, el elemento subjetivo es el ser humano, y no la persona: la personalidad es la entrada del ser humano en el mundo jurídico (Pontes de Miranda, 2012: 57).

Según Kolher, «personalidad» es un término técnico del derecho privado que significa «aptitud para ser sujeto de derecho» (en Pontes de Miranda, 2012: 265). Se percibe que la norma jurídica no tiene el poder de crear la personalidad, por más que exprese tal pretensión, pero sí de determinar el momento en que el individuo tendrá la capacidad de derecho.

Son derechos de la personalidad todos aquellos necesarios para la realización de la personalidad y su inserción en las relaciones jurídicas, siendo intangibles incluso por el Estado.

\section{Derecho a la información}

El derecho a la información debe compatibilizarse con la necesidad de protección de los derechos de la personalidad que se refieren a la honra, la intimidad y la vida privada de cualquier ciudadano, de modo que no se produzcan abusos en el control de la difusión de la información.

Algunos autores entienden que los derechos de la personalidad ocupan un lugar privilegiado en eventual colisión con los demás derechos constitucionales. Según el texto de Pedro Pais Vasconcellos:

Los derechos de la personalidad son supralegales y jerárquicamente superiores a otros derechos, incluso en relación con los derechos fundamentales que no sean derechos de la personalidad, como, por ejemplo, el derecho de libertad de prensa, que no se sitúa en los derechos de la personalidad (Vasconcellos, 1999: 36).

Para otros autores, el ejercicio regular de un derecho puede conllevar ilicitudes. O sea, será abusivo el ejercicio de un derecho cuando se ejecute de forma contraria a la buena fe y las buenas costumbres, porque la libertad pública no puede prestarse a tutelar conductas ilícitas. Sin embargo, esta explicación es incompleta. Primero, porque no toda la información sobre la vida privada puede ser considerada ilícita. Segundo, porque existe una línea tenue entre lo que puede o no ser informado y no existe una legislación específica sobre el tema. 
En la Constitución de la República Federativa del Brasil se dispone que «se garantiza todo el derecho a la información». Se asegura la búsqueda o prospección de las informaciones necesarias para elaborar una noticia o hacer una crítica (artículo 5, apartado 14).

De esta forma, el derecho a la información, derecho de todo individuo protegido por la Constitución, consiste en no obstruir el derecho a recoger informaciones de carácter público y personal, especialmente en lo referente a la cosa pública, considerando la prevalencia del principio de publicidad de los actos administrativos, dejando aparte, incluso, la confidencialidad de la fuente cuando fuera indispensable para el ejercicio profesional.

\section{La verdad tiene diversas caras}

El derecho a la verdad es un derecho fundamental que puede ser ejercido por cualquier ciudadano a la hora de recibir informaciones de interés público que estén en poder del Estado o de entidades privadas.

El derecho a la verdad se refiere solo a la verdad que se puede demostrar. La posibilidad de demostración es lo que interesa, pues es lo que identifica las convicciones. No se puede exigir solamente que se diga la verdad, ya que si algo se enuncia existe el derecho a que se pruebe o que se declare falso, en razón de un valor hipotético a la honra, en detrimento de su valor real, ya que todos se presumen buenos y correctos.

A este respecto, Pontes de Miranda señala:

En la Constitución de 1988, artículo 5, V, primera parte, se refiere como derecho preconstitucional, el derecho de la personalidad, que la propia Constitución protege, o el derecho de réplica: la norma jurídica basta. Cualquier persona, a la que, en Brasil, se haya ofendido su derecho a la personalidad a la honra, o a la verdad, tiene derecho, pretensión y acción para una respuesta. El derecho de réplica es el derecho de negar, todo o parte, de los enunciados del hecho que alguien emitió (Pontes de Miranda, 2012: 23).

Manifestándose en las situaciones más diversas, la verdad ahora se especifica como un derecho a respetar, o como una obligación a cumplir, o como una pretensión a la que sustraerse. Y vuelve al tema de quien es el titular de estos derechos, obligaciones, pretensiones. En una sociedad ávida de informaciones y continuamente productora de representaciones, es innegable que en estas últimas tienen una relevancia particular.

Surgen nuevos intercambios, y con ellos nuevos equilibrios. Servicios a cambio de verdad, seguridad a cambio de verdad, confianza a cambio de verdad. De esta manera el mercado, las instituciones públicas y la política afectan de diferentes maneras a las personas y configuran sus relaciones en torno a representaciones «verdaderas», construidas para ser funcionales de acuerdo con los objetivos que gradualmente se persiguen. Hoy, el simple hecho de «estar en sociedad» no se puede separar de un interrumpido flujo de la información que las personas difunden en una multiplicidad de direcciones, abasteciendo a otros las múltiples verdades que cada persona porta. 
Frente a la sistemática pretensión social de desvelarse surge una obligación de verdad que altera el propio «coraje» de la verdad porque, en estas situaciones, el verdadero coraje consiste en negarse a someterse a este escrutinio permanente y despiadado.

De nuevo la referencia a un sujeto abstracto cede al esculpirse de realidades en las que las personas están inmersas, a los entrelazamientos que les marcan la existencia, a los diferentes modos en los que la persona es "puesta en escena». La verdad es continuamente puesta a prueba, inmersa en una serie de conflictos: memoria u olvido, transparencia o privacidad, libre construcción de la personalidad o subordinación a controles, identidad inclusiva o excluyente.

\section{Derecho a la igualdad}

El contenido del artículo 5 apartado 5 de la Constitución del Brasil se dirige a todos los poderes, como una regla introducida en las Constituciones anteriores. El concepto de igualdad ante la ley es técnico. No es necesario buscarle fundamentación filosófica, y es erróneo confundirlo con anhelos o propósitos de equidad o de justicia social, como lo hicieron y hacen algunos juristas, que así diluyen, por cierto, la practicidad del principio de isonomía.

La principal disposición del título del artículo 5 de la Constitución Brasileña ${ }^{2}$ es el principio de igualdad formal, o principio de isonomía, según el cual «todos son iguales ante la ley». Esto no significa que todas las personas reciban un trato igual por las leyes brasileñas, sino que tendrán un tratamiento diferenciado en la medida de sus diferencias. Lo que la Constitución exige es que las diferencias impuestas sean justificables por los objetivos que se pretende alcanzar por la ley.

De esta forma el artículo consta de tres partes:

- el enunciado del principio de isonomía;

- la indicación genérica de los derechos individuales inviolables y sus destinatarios; $y$,

- los términos en los que estos derechos se garantiza, especificado en los apartados.

La Constitución garantiza la inviolabilidad de los derechos a la vida, a la libertad, a la igualdad, a la seguridad y a la propiedad en los términos indicados en los apartados del artículo 5, además de otros derivados del régimen y principios por ella adoptados o de los tratados internacionales de los que la República Federal de Brasil sea parte. La inviolabilidad es un determinante normativo, como objeto de la garantía, donde el artículo definido revela el contenido intrínseco de los derechos enunciados, es decir, que ellos contienen en sí mismos la calidad esencial de ser inviolables.

2. El título señalado expresa: «Todos son iguales ante la ley, sin distinción de cualquier naturaleza, garantizando - bien sea a los brasileños o a los extranjeros residentes en el país - la inviolabilidad del derecho a la vida, a la libertad, a la igualdad, a la seguridad y a la propiedad en los términos siguientes» (artículo 5). 


\section{Honra: el sentimiento de la propia dignidad}

El artículo 5 apartado 10 de la Constitución del Brasil establece que son inviolables la intimidad, la vida privada, la honra y la imagen de las personas, asegurando el derecho a la indemnización por el daño material o moral derivado de su violación.

La Convención Interamericana de los Derechos Humanos -el Pacto de San José de Costa Rica-, vigente en Brasil, reconoce la protección a la honra en el artículo 11, disponiendo que «toda persona tiene derecho al respeto de su honra y al reconocimiento de su dignidad».

La honra es un atributo inherente a la personalidad cuyo respeto a su esencia refleja la observancia del principio de la dignidad de la persona humana. La dignidad personal, el sentimiento y la conciencia de ser digno, sumados a la estima y la consideración moral de los otros, forman parte del contenido de lo que se llama honra. El derecho de la personalidad a la honra es absoluto, público y subjetivo, y aquel que lesiona la honra comete un ilícito absoluto contra las personas físicas o jurídicas.

De acuerdo con Arthur von Schopenhauer, la honra se traduce en el sentimiento de propia dignidad (honra interna o subjetiva), en la estima social, la reputación y la buena fama (honra exterior u objetiva) (Schopenhauer, 2002: 80). Se divide en honra subjetiva, que trata del propio juicio valorativo que la persona tiene de sí mismo, y en honra objetiva, que se refiere a la reputación que la colectividad tiene de alguien (Bitencourt, 2014: 328). Tanto la violación de la honra objetiva como de la subjetiva conllevan, en el campo civil, la reparación del daño moral. La honra integra, por lo tanto, los derechos de la personalidad en el ámbito psíquico.

Conforme a lo expresado por Carlos Alberto Bittar, «el ordenamiento jurídico prohíbe todas aquellas prácticas tendientes a la contención de la mente o a la intimidación mediante el miedo, o por el dolor, en fin, que obnubilen el discernimiento psíquico» (Bittar, 2001: 116-117).

La difusión de un hecho de interés público, así como la exposición de un hecho criminal, cuando es cierto, no caracteriza violación a la honra. Sin embargo, siendo falsos los hechos imputados existe un daño al titular de la honra violada.

El Código Civil brasileño del 2002 protege la honra en los términos siguientes:

Artículo 20. Salvo autorización, o necesidades de la administración de justicia o mantenimiento del orden público, la divulgación de escritos, la transmisión de palabra, o la publicación, la exposición o utilización de imágenes de una persona podrán prohibirse, a solicitud y sin prejuicio de la indemnización que debiera, si se afecta la honra, la buena fama o la respetabilidad, o se destinen a fines comerciales.

Es pues importante el amparo a la honra respecto de las personas físicas, que se encuentra alojada en lo más íntimo del ser del individuo. Afectar la honra de un sujeto es herir el ser humano y puede representar un daño mayor que las ofensas físicas, pues afecta a la psique y al sentimiento de las personas. Resulta imposible la reparación in- 
tegral de la agresión a la honra de un individuo. Lo que puede existir es una retracción, o la compensación material, dependiendo de la gravedad de la ofensa a este derecho.

\section{La imagen como identificación del individuo}

La imagen significa la reproducción física de la persona, en todo o en parte, por cualquier medio como la pintura, la fotografía o una película (Pontes Miranda, 2012: 55). Este es el sentido que se da al apartado 28, letra $a$, del artículo 5 de la Constitución Federal que, en el apartado 10 del mismo artículo, la considera como patrimonio moral. La imagen se presta a ejemplificar la diferencia entre la disponibilidad del ejercicio y no del propio derecho, teniendo en cuenta que una de las características en los derechos de la personalidad es la inalienabilidad.

El derecho a la imagen es un derecho de la personalidad cuando tiene por contenido la reproducción de formas, voz, gestos, de manera que identifiquen al individuo, como la representación física de la persona, relativa a la forma plástica como un todo y partes separadas del cuerpo (boca, cara, piernas, senos, etc.), pudiendo ser expresadas a través de la pintura, fotografía, escultura, televisión, cine y últimamente vía internet. Ninguno puede ser expuesto públicamente sin su consentimiento, rigiéndose el derecho a la imagen por el principio de la exclusividad y de la elección personal.

La principal relación que existe entre el derecho sobre la historia de la propia vida y el derecho a la imagen reside en la reproducción biográfica, en la medida en que el relator, ya sea por escrito, con fotos o pinturas, ya sea en una película, ambos recogiendo hechos distorsionados, mentirosos o tergiversados, conllevarán la indemnización por los daños causados siendo responsable el autor del guion, el productor y el coproductor. De aquí la necesidad de la autorización expresa del biografiado para quien va a hacer la película. Se excluyen de la obligatoriedad de la autorización las publicaciones con finalidad científica, cultural o didáctica.

Si a pesar de la autorización se distorsiona la finalidad para la cual la imagen se concibió, persiste la posibilidad de una demanda indemnizatoria. Será posible, igualmente, la reparación indemnizatoria, cuando se trate de una persona notoria, cuyo reconocimiento social sea importante y la publicación indebida o la biografía maliciosa le cause daños irreparables.

En los casos de personas públicas, de servicios a la justicia, a la policía, o fines culturales, no existe daño a la imagen siempre que no interfiera en la vida privada, con reproducción de imágenes inadecuadas y ofensivas. Según Carlos Alberto Bittar:

Esto conforma la propia naturaleza del derecho en la pantalla, que se relaciona con la facultad que la persona tiene de escoger las ocasiones y los modos por los cuales debe aparecer en público. Se basa, como los demás derechos de este orden, en el derecho a la personalidad humana, teniendo su origen histórico en el denominado right of privacy, evitándole exposiciones públicas no deseadas. Pero con la evolución, acabó por asumir contornos propios, envolviendo la defensa de la figura en sí, independientemente del lugar en que se encuentre, consistiendo, en esencia, en el derecho de impedir que otro 
utilice - sin previa y expresa anuencia del titular, en escrito revestido de las formalidades legales - de su expresión externa, o de cualquiera de los componentes individualizadores (aunque, en la doctrina, todavía se presente vinculado al derecho al resguardo, o a la intimidad, que entendemos distinto) (Bittar, 2001: 88-89).

Se debe resguardar la imagen moral, evitando la lesión a la honra, a la reputación, al decoro y a la intimidad, principalmente en lo relativo al derecho a la imagen.

La imagen de las personas muertas también puede verse afectada, por lo que el derecho a la imagen no termina con el óbito, concerniendo a los herederos la acción de la defensa, incluso mediante la solicitud de la reparación por daños eventualmente causados.

\section{El derecho a resguardarse: la intimidad}

El derecho a la intimidad es aquel que preserva al individuo del conocimiento ajeno, reservándose su propia vivencia.

Para referirse a este derecho los juristas utilizan diversas terminologías: en los Estados Unidos se denomina right of privacy; en Francia, droit à la privée y droit à l'intimité; en Italia, diritti alla riservatezza. En Alemania, la Corte Constitucional, en base al Preámbulo de la Ley Fundamental ${ }^{3}$ de este país, reconoció la existencia de un derecho fundamental a la autodeterminación sobre las informaciones de carácter personal: Recht auf informationelle Selbstbestimmung.

En Brasil, existen los que prefieren hablar de derecho a la vida privada y derecho a la privacidad. Según Celso Ribeiro Bastos, el apartado 10, del artículo 5 de la Constitución Federal:

Ofrece protección al derecho a la reserva de la intimidad, así como al de la vida privada. Consiste en la facultad que tiene cada individuo de obstaculizar la intromisión de extraños en su vida privada y familiar, así como de impedirle el acceso a informa-

3. Traducción libre: «Consciente de su responsabilidad ante Dios y ante los hombres, animado de la voluntad de servir a la paz del mundo, como miembro con igualdad de derechos de una Europa unida, el pueblo alemán, en virtud de su poder constituyente, se ha otorgado la presente Ley Fundamental. Los alemanes, en los Länder de Baden-Wurtemberg, Baja Sajonia, Baviera, Berlín, Brandeburgo, Bremen, Hamburgo, Hesse, Mecklemburgo-Pomerania Occidental, Renania del Norte, Westfalia, Renania-Palatinado, Sajonia, Sajonia-Anhalt, Sarre, Schleswig-Holstein y Turingia, han consumado, en libre autodeterminación, la unidad y la libertad de Alemania. La presente Ley Fundamental rige, pues, para todo el pueblo alemán». Texto original: «Grundgesetz für die Bundesrepublik Deutschland - Präambel -Im Bewußtsein seiner Verantwortung vor Gott und den Menschen, von dem Willen beseelt, als gleichberechtigtes Glied in einem vereinten Europa dem Frieden der Welt zu dienen, hat sich das Deutsche Volk kraft seiner verfassungsgebenden Gewalt dieses Grundgesetz gegeben. Die Deutschen in den Ländern Baden- Württemberg, Bayern, Berlin, Brandenburg, Bremen, Hamburg, Hessen, Mecklenburg-Vorpommern, Niedersachsen, Nordrhein Westfalen, Rheinland-Pfalz, Saarland, Sachsen, Sachsen-Anhalt, Schleswig Holstein und Thüringen haben in freier Selbstbestimmung die Einheit und Freiheit Deutschlands vollendet. Damit gilt dieses Grundgesetz für das gesamte Deutsche Volk». 
ciones sobre la privacidad de cada uno, y también impedir que se divulgue información sobre esta área de la manifestación existencial del ser humano (Bastos, 2010: 305).

Sobre el derecho a la intimidad, Robert Alexy menciona, en su obra Teoría de los derechos fundamentales, la teoría de las esferas, en la cual es posible separar tres esferas con decreciente intensidad de protección, que son: la esfera más interna, ámbito último intangible de la libertad humana, caracterizado por ser el ámbito más íntimo, la esfera íntima intangible y conforme a la interpretación del Tribunal Constitucional Alemán, el ámbito del núcleo absolutamente protegido de la organización de la vida privada, que comprende los asuntos más secretos que no deben llegar a conocimiento de los otros debido a su naturaleza extremamente reservada; la esfera privada amplia, que abarca el ámbito privado en la medida en que no pertenece a la esfera más interna, incluyendo asuntos que el individuo da a conocer a otra persona de su confianza, excluyendo al resto de la comunidad; y la esfera social, que engloba todo lo que no fue incluido en la esfera privada amplia, o sea, todas las materias relacionadas con las noticias que la persona desea excluir del conocimiento de terceros (Alexy, 2012: 80). ${ }^{4}$

Con el objeto de encontrar ese ámbito más íntimo e interno del individuo, basta averiguar si existe un comportamiento de una persona que en ningún aspecto se refiera o afecte a la esfera de otras o a los intereses de la vida en comunidad. De esta forma, determinadas situaciones y formas de comportamiento de un individuo conducirían a una prioridad absoluta del principio de libertad negativa junto con el principio de la dignidad de la persona frente a otros principios concebibles. Sin embargo, hay que recordar que no existe un derecho absoluto, aunque así los consideremos, no queda lejos el ámbito más interno de la personalidad del individuo a proteger por reglas o principios.

La intimidad, como exigencia moral de la personalidad para que en determinadas situaciones se deje al individuo «en paz», constituyendo un derecho a controlar la indiscreción ajena en los asuntos privados que solo a él le interesan, tienen como uno de sus fundamentos el principio de exclusividad, formulado por Hannah Arendt en base a Kant (Arendt, 2010: 406). ${ }^{5}$

Este principio, buscando amparar a la persona de los riesgos originarios de la pre-

4. En el mismo sentido, el Código Deontológico del Periodista, ítem 9: «El periodista debe respetar la privacidad de los ciudadanos excepto cuando fueran causas de interés público o la conducta del individuo contradiga, manifiestamente, valores o principios que públicamente defiende. El periodista se obliga, antes de recoger declaraciones o imágenes, a tener en cuenta las condiciones de serenidad, libertad y responsabilidad de las personas implicadas».

5. Observa la autora lo siguiente: «El fundamento, por tanto, para el derecho a la intimidad, es la exclusividad. Esta, a diferencia del derecho a la información (derecho humano en la esfera del espacio público, como acceso a todo aquello que se refiere al mismo, permitiendo una adecuada, autónoma e igualitaria participación de los individuos en la esfera pública, evitando el efecto deletéreo de la mentira), es el que mantiene lejos de terceros aquello que es propio, exclusivo al individuo. Es también colaboradora de la esfera pública, pues ayuda a delimitar lo que concierne a cada espacio. La invasión de este derecho y la consecuente emergencia de lo que es intimo al público, ocurre en la banalización de ambas partes». 
sión social niveladora y de la fuerza del poder político, conlleva esencialmente tres exigencias: la soledad (o deseo de estar solo), el secreto (exigencia de confidencialidad) y la autonomía (la libertad de decidir sobre sí mismo como centro emisor de informaciones).

En el ámbito público, la misma situación que ocurre con el derecho a la honra viene siendo aceptada por la doctrina como relevante para hacer valer o no el derecho a la intimidad. Cuando el agente público (funcionario público o aquel que, de alguna forma, integre el servicio público) practica actos inherentes a su cargo o función, se somete a la exposición de su privacidad e intimidad, teniendo en cuenta la relevancia de sus actos frente a la sociedad. De esta manera, es de constatar, como observamos en la sección anterior, que el derecho a la privacidad ofrece mayor protección a los ciudadanos comunes y corrientes que a los hombres públicos o celebridades. Sin embargo, se comprueba con bastante propiedad que las personas públicas no sufren una supresión de su intimidad, sino una limitación.

Considerando la teoría de las esferas concéntricas, la jurisprudencia constitucional germana (Sentencia del Tribunal Constitucional Alemán, núm. 1, BvR 472/14, de 24 de febrero de 2014$)^{6}$ hace referencia a la esfera de la intimidad como un contenido esencial a los derechos de la personalidad, lo que hace que la colisión de los derechos a la libertad de expresión y a la intimidad no sea susceptible de cualquier ponderación proporcional (Szaniawski, 1993: 176-180). De esta forma, la información que colisiona con el derecho constitucionalmente tutelado de la intimidad ni siquiera estaría sujeta a la observancia de las exigencias mínimas de la razonabilidad y la proporcionalidad. Prevalecería siempre el derecho a la intimidad.

\section{Derecho al olvido}

El contexto actual sobre la información — de gran importancia para las relaciones sociales, económicas y educativas - camina al lado de cuestionamientos elementales, como la de conseguir un ambiente informacional digno y coherente con los principios y derechos fundamentales.

Entre los cuestionamientos que existen, merece especial atención el derecho al olvido. No hacemos referencia, queremos resaltar, a la censura, sino a los límites de la información, cualquiera que sea su fuente. Además, el discurso sobre la censura, vinculado con la libertad de prensa y de expresión, ni siquiera puede pasar por aquí. Nos referiremos, especialmente, al problema sobre informaciones personales e interpersonales, a la propia libertad de las personas a informarse, ser informadas e incluso a no ser informadas o no divulgarse su información. Afrontaremos la discusión acerca del alcance de la dignidad y del right to be alone.

La velocidad con la que circulan las informaciones no nos permite que se piense solamente en un mecanismo de abstención o represión, sino en medios eficaces para

6. El texto del fallo se encuentra disponible en http://bit.ly/3862S5O. 
evitar los abusos y excluir o impedir que se generen perjuicios continuos u onerosos. La velocidad con la que se disemina la información suele ser la misma con la que se olvida la situación, desde que desaparece en los medios de información. ¿Cuánto tiempo puede mantenerse una información negativa? ¿Cuánto tiempo puede informarse algo sobre una persona, sea positivo o negativo, y qué información se puede mantener sobre alguien?

El actual estado de la tecnología, iniciado con el desarrollo de las primeras herramientas informáticas de acceso y catalogación, necesita informaciones. La creación de los grandes bancos de datos, disponibles a través de internet, y aliados, aún, al desarrollo constante de los servicios de búsqueda y de automatización en su clasificación, representa un completo cambio en el paradigma de archivo histórico de las informaciones producidas por un determinado individuo u organización.

Durante la mayor parte del desarrollo humano, la memoria, como concepto genérico para guardar la información, siempre se presentó como un recurso limitado y de limitado acceso para la gran masa social. Es, en síntesis, costosa. En tiempos antiguos, incluso con toda la preparación y desarrollo para la elaboración de escritos históricos, pocos son los que llegaron intactos a nuestra era, vista la fragilidad del soporte sobre el cual reposaban tales memorias históricas. Este mismo hecho se repite a lo largo de todo el desarrollo histórico humano. Los medios de archivo de la memoria colectiva de la sociedad siempre fueron costosos e inseguros. Como ejemplo, recordemos la destrucción de la Biblioteca de Alejandría, donde innumerables estudios históricos se perdieron. Es más, al pensar en historias particulares de los individuos, el panorama se presenta más oscuro. Hasta inicios del siglo XX, la única tecnología comúnmente disponible era el papel y la pluma. Pocos eran los que podían tener acceso a la máquina mecánica de escribir (dactilografía), y mucho menos aun los que podían pensar que un día llegarían a publicar una obra en una gráfica.

Mientras que, en tiempos más recientes, todo parece haber cambiado. Después del largo desarrollo de la microinformática, iniciada a mediados del siglo XX, el concepto previo de almacenamiento de las informaciones sufrió un cambio total. Con cada tecnología lanzada por las grandes empresas del ramo, se constató también una acentuada caída del valor necesario para adquirir espacio de almacenamiento de informaciones, vinculado, también, con el menor espacio físico que ocupan, haciendo el almacenamiento cada vez más barato y omnipresente en la sociedad contemporánea. Además de esto, se han desarrollado mecanismos de catalogación, softwares inteligentes que tienen como único objetivo catalogar y poner a disposición, de forma rápida, para el usuario, todos los «recuerdos» a los que quiera tener acceso. Para rematar esta situación, se han desarrollado las posibilidades de compartir estas informaciones en tiempo próximo al real mediante internet, posibilitando que diversas personas compartan las memorias entre ellas, incluso existiendo diversas barreras geográficas. Los cambios pueden observarse en pequeños actos diarios de la población. Solo como ejemplo se puede mencionar el caso del comportamiento de las personas relativos a las fotografías.

En el inicio del siglo XX, la fotografía era restringida a las más altas esferas sociales. 
Con el desarrollo de la tecnología, de forma notoria tras la Segunda Guerra Mundial, junto con el abaratamiento de la tecnología fotográfica, esta se hace accesible al público en general. Aunque todavía existían barreras respecto a la disponibilidad del archivo, cada evento social se registraba en un pequeño número de imágenes, y las fotografías todavía tenían que pasar por un lento proceso de «revelación», con riesgo de perder todo el material. El ejemplo de la fotografía se puede trasladar fácilmente a la mayor parte de las herramientas de la memoria humana: libros que dependían de las bibliotecas o librerías; periódicos, de circulación diaria y transportados a otros lugares; cartas que dependían de los servicios postales; el conocimiento científico que dependía del intercambio personal de las investigaciones y de los resultados obtenidos.

Hoy vivimos una inversión completa de estos paradigmas anteriormente existentes. El gran paradigma social de la memoria ahora es otro: se abandona el olvido. Las informaciones ya no se producen por un único poder dominante, sino por cualquier actor social, y son catalogadas, relacionadas entre sí, puestas a disposición de manera ilimitada y, principalmente, almacenadas ad eternum, muchas veces sin tener noción de aquellos a los que se refieren. Se trata de la llamada sociedad de la información, expresión que surgió después de un enorme desarrollo de las tecnologías informáticas y de la conexión en las redes, pasando por fases y revoluciones, hasta conseguir el pleno desarrollo con internet, como se conoce actualmente.

La cuestión pasa a ser relevante cuando se constata la actual ausencia de barreras en la producción y transmisión de información, cualquiera que sea su naturaleza o finalidad. Con la segunda revolución de internet, la también llamada Web 2.o, se observan cambios en las relaciones entre los individuos y entre estos y la propia red mundial. Internet pasó en pocos años de ser el gran banco de datos de referencias científicas a herramientas de uso sencillo y trivial, permitiendo que más y más personas puedan utilizar el espacio interconectado para publicar sus propias experiencias, llegando al extremo de las llamadas redes sociales, espacios destinados a reproducir las interacciones humanas.

Con toda la gama de herramientas disponibles para la investigación de datos en línea, vinculada a un gran número de informaciones, datos personales o incluso vestigios que el ser humano deja, de forma consciente o no, durante toda su vida, en los espacios electrónicos se hizo posible elaborar su perfil de comportamiento. Muchas veces, el individuo ya no tiene la posibilidad de presentarse ante un nuevo grupo social, no pudiendo disociarse de su persona pasada, aunque ésta haya sido abandonada en otras épocas, modificada en razón de nuevas experiencias a las que el individuo se haya sometido a lo largo de su vida.

El problema planteado en este estudio se refiere a los actuales medios electrónicos de producción de informaciones que nada olvidan. Todo está catalogado y archivado. La memoria ya no es cara; hoy es trivial. Salimos de la edad del olvido hacia la edad del recuerdo total, para presentar el cambio de panorama en cuanto al archivo total de informaciones disponibles en la red mundial de computadoras, que tuvo eco a la hora de teorizar el derecho al olvido presentado en Delete: The virtue offorgetting in the 
digital age (Mayer-Schönberger, 2009). Todo lo que se produce de forma electrónica se mantiene, cataloga e indexa, y está a disposición con solo hacer un clic en el ratón, pudiendo, incluso a regañadientes del autor, volver a atraer la atención del público, con los más diversos objetivos, aunque el contenido publicado ya no tenga que ver con lo que piensa el autor.

De esta manera, se puso de moda el reconocimiento del «derecho al olvido», el cual, según Juliana Abrusio Florêncio, puede definirse como «el derecho de los individuos de no tener procesados y tener borrados sus datos cuando no sean necesarios para propósitos legítimos» (Florêncio, 2011: 216), como medio de garantizar la libertad de desarrollo de la personalidad en la sociedad de la información. Asegurando que no se vinculen ad eternum a sus producciones intelectuales, ni las producciones de otros sobre él mismo, siendo posible alterar la persona social que presenta.

La sociedad de la información es todo este contexto, como hemos dicho, que cambia y dicta comportamientos y el funcionamiento de la sociedad. Sus efectos alteraron las formas de comunicación, las relaciones interpersonales, las relaciones, las formas de trabajo, el consumo y la propia vida en sociedad.

El derecho al olvido no puede verse, en consecuencia, como un delirio moderno. En el derecho penal es más fácil de visualizar este derecho y existe hace tiempo. Pensemos en lo siguiente: un sujeto comete un crimen, es juzgado, condenado y cumple su condena. Los registros sobre este hecho no pueden utilizarse permanentemente contra este sujeto. Esto no ocurre solo en los casos de condena, sino también en situaciones en las que el sujeto no tiene condena, pero termina condenado por la información.

Más allá: una persona es víctima de un delito sexual. Este hecho se sube a la red. ¿Cuánto tiempo puede mantenerse esta información? ¿Y las referencias sobre el hecho? $¿ \mathrm{Y}$ alguien que haya sido despedido por justa causa, por ejemplo? ¿Se debe mantener permanentemente en la red esta información, aunque sea verídica? O sea, el sujeto comete un error, como el que cualquiera de nosotros podemos cometer, pero queda permanentemente manchado, aunque sea indirectamente.

Esto no puede ser así, pues estaríamos hablando de un tratamiento degradante, prohibido por la Constitución brasileña. Le afecta tanto a la persona que no tiene la forma de conseguir una segunda oportunidad, ni sobrevivir autónomamente. No puede confundirse la existencia de una pena con el necesario proceso precedente, pues, en la práctica, se tiene una pena sin proceso. El sujeto es castigado por la sociedad, aunque inocente o sin haber sido procesado, sintiendo los efectos de la pena. De cualquier forma, no puede dar lugar a un tratamiento degradante.

Por esto, el derecho al olvido es un derecho fundamental de la dignidad de la persona humana y de la inviolabilidad personal según lo dispuesto en la Constitución de la República Federativa de Brasil (artículo 1, apartado 3; artículo 1, apartado X, y artículo 5, apartado 3) y en Código de Proceso Penal de Brasil (artículos 93 y 748).

Las raíces del derecho al olvido se pueden encontrar en el artículo «The right to privacy», publicado en la Harvard Law Review, en 1890, considerado el marco inaugural de la formulación de la privacy (Warren y Brandeis, 1890). Preocupados por las cons- 
tantes intromisiones en la vida personal y familiar por parte de periodistas, $y$ teniendo como base el derecho a estar solo (right to be alone), intentaron poner distancia entre el derecho a la privacidad y el derecho a la propiedad, con la tesis de que la common law aseguraba a cada individuo el derecho a determinar hasta qué punto sus pensamientos, sentimientos y emociones deberían comunicarse a otras personas. Concluyeron que el right to privacy provenía de la inviolabilidad de la personalidad, sin embargo, sostenían que no podía impedirse la publicación de hechos de interés público. De estas premisas se produjo, inevitablemente, una protección jurídica de este bien, que faculta a cada persona a delimitar un ámbito en el cual pueda libremente desarrollar su personalidad, sin intrusión, curiosidad e indiscreción.

A partir de este núcleo sustancial, algunos aspectos de la intimidad se protegen por la vía de la defensa (status negativus), como la inviolabilidad del domicilio, la protección de las comunicaciones escritas, orales y telemáticas, de las costumbres personales, del comportamiento, de las actividades personales y también de determinados aspectos de la vida de las otras personas con las cuales se tiene una estrecha vinculación familiar que no interesan a la colectividad. Efectivamente, con estas ideas se completa el clásico derecho de defensa (status negativus), la versión negativa de la intimidad, con la posibilidad de ejercer tal derecho de forma positiva, esto es, denegando o concediendo informaciones personales (Doneda, 2006).

Esta nueva dimensión de la intimidad también comprende la facultad del individuo de elegir (status positivus) la revelación o no de informaciones que directamente le conciernen, lo que constituye la prefiguración de la denominada autodeterminación informativa (Murillo de la Cueva, 1990). Con razón, Stefano Rodotà describe que en el último siglo hubo un proceso de «reinvención de la privacidad», subsidiado con la implantación de valores democráticos (Rodotà, 2008: 14).

La dilatación del concepto de privacidad, desde su formación primigenia por Warren y Bradeis, fue fruto de la reflexión doctrinal y de las elaboraciones jurisprudenciales sobre el control, por parte del titular, de las informaciones que se refieren a su persona o a su familia. Construido a partir de la noción de intimidad, actualmente se encamina a dotar a las personas de protección jurídica frente a la informatización de los datos personales (ad se-ad alteros/interioridad-alteridad) (Warren y Bradeis, 1890).

Rodotà pondera que las definiciones «reinventadas» sobre la privacidad no se excluyen mutuamente. En verdad, marcan una inserción paulatina de nuevas facetas de la libertad con un concepto expansivo de la privacidad. En este sentido, argumenta con propiedad, que no hay que hablar de etapas generacionales de la privacidad, pues las definiciones más recientes no superan a las anteriores, «exactamente porque no están basadas en diferentes requisitos y operan en niveles diferentes» (Rodotà, 2008: 15). Propone que con la fragilidad de la concepción de la privacidad como el «derecho a estar solo», el centro de gravedad de este concepto se enfoca "por la posibilidad de que cada uno controle el uso de las informaciones que le concierne» (Rodotà, 2008: 24). 


\section{Los límites de la libertad de expresión: la intimidad, la honra y la vida privada}

\section{Naturaleza de los derechos fundamentales}

Las primeras inspiraciones para las declaraciones de los derechos en Francia fueron el pensamiento cristiano y la concepción del derecho natural sobre condiciones reales, pues durante el siglo XVIII se manifiesta la contradicción entre el régimen de la monarquía absoluta y una sociedad tendiente a la expansión comercial y cultural. Y también bajo condiciones subjetivas, en las cuales destacaron el pensamiento cristiano primitivo, que contenía un mensaje de liberación del hombre porque ha sido creado a imagen de Dios, y esta dignidad pertenece a todos sin distinción; la doctrina del derecho natural de los siglos XVII y XVIII de naturaleza racionalista sustenta la tesis de derechos innatos teniendo como base para el reconocimiento de un conjunto de derechos considerados como inherentes a la persona humana; el pensamiento iluminista, afirmación del individualismo por encima de los valores sociales. Según José Alfonso da Silva, estos fundamentos fueron superados por el proceso histórico-dialéctico de las condiciones económicas y que dieron lugar al nacimiento de nuevas relaciones objetivas (Silva, 2009b: 17).

De esta ampliación de los derechos fundamentales se afirma que los derechos fundamentales del hombre constituyen:

[La] expresión más adecuada, porque, además de referirse a principios que resumen la concepción del mundo e informan la ideología política de cada ordenamiento jurídico, se reserva para designar, a nivel del derecho positivo, aquellas prerrogativas e instituciones que concretiza en garantías de una convivencia digna, libre e igual de todas las personas. En su cualidad fundamental se encuentra la indicación de que se trata de situaciones jurídicas sin las cuales la persona humana no se realiza, no convive y, a veces, ni siquiera sobrevive; fundamentales del hombre en el sentido de que todos, por igual, deben ser, no solo formalmente reconocidos, sino concretados y materialmente efectivos (Silva, 2009b: 178).

Es indispensable afirmar que los derechos fundamentales tienen naturaleza relativa, lo que significa que tales derechos no tienen carácter absoluto, encontrando límites en los demás derechos igualmente reconocidos y amparados en la Constitución de la República.

\section{Conflicto de derechos fundamentales}

La materia en cuestión es de una relevancia insuperable, teniendo en cuenta que se trata del embate entre lo público y privado, la discusión entre el derecho a la intimidad y la libertad de información.

Según Paulo Bonavides, la relación de los principios con el derecho pasa por tres fases distintas: la iusnaturalista, la positivista y la pospositivista. En la fase iusnaturalista, los principios se consideran a partir de una perspectiva abstracta, rechazando su carác- 
ter normativo, y reconociendo su dimensión ético-valorativa, inspiradora del ideal de justicia (Bonavides, 2013: 268).

El sentido ético-valorativo iusnaturalista se desarrolla en la edad moderna, y tiene como axioma fundamental la naturaleza humana y sus principios inmanentes. De acuerdo con esta idea, los principios extraídos del ordenamiento jurídico positivo no son suficientes para llenar los vacíos de la ley, lo que impone al intérprete, recurrir a los principios del derecho natural para designar una solución justa al caso concreto sometido a análisis (Nader, 2012: 174).

Bajo la óptica de los iusnaturalistas modernos, los principios están impregnados de ideal subjetivo de justicia, concepto que, a pesar de ser loable, no resiste las críticas de otras escuelas del derecho, como la escuela positivista, sobre todo en lo que respecta a su indeterminación y al método de aplicación, ya que el valor de la justicia puede ser interpretado a partir de las más variadas ideologías, dando lugar a demasiadas inseguridades, lo que acaba llevando a esta concepción al descrédito (Bonavides, 2013: 271).

Surge entonces la concepción positivista de principios, presentándolos como verdaderas válvulas de seguridad introducidas en las codificaciones, sin poderse oponer a la ley. Para esta escuela, los principios funcionan como reglas para cubrir los vacíos, que se prestan, exclusivamente, a ayudar en la aplicación de la ley, de forma subsidiaria, con el objetivo de llenar las lagunas y, al mismo tiempo, aportar mayor seguridad al sistema jurídico, de esta manera concebido por esta línea de pensamiento (Bonavides, 2013: 271-272). Pero el iuspositivismo, al hacer de los principios del orden constitucional meras pautas programáticas supralegales, ha señalado, por regla general, su falta de normatividad, estableciendo, por tanto, su irrelevancia jurídica (Bonavides, 2013: 271).

Las nuevas Constituciones, promulgadas en las últimas décadas del siglo XX, llevan en su cuerpo verdaderas normas jurídicas que pueden aplicarse efectivamente y que presentan las siguientes características:

- norma superior del ordenamiento jurídico;

- norma vinculante; $y$,

- norma de aplicación inmediata, independiente del desarrollo de una producción legislativa de jerarquía inferior.

Estas Constituciones profesan la hegemonía axiológica de los principios como verdaderas normas, de las cuales emanan las demás reglas del ordenamiento jurídico correspondiente. Algunos principios, si no llegan a ser normas en el sentido estrictamente técnico de la palabra, como ratio legis, son derecho positivo, y, expresados por los medios interpretativos adecuados, toman forma concreta (Bonavides, 2013: 273).

En cuanto a los principios estrictamente normativos, dejan de ser solamente ratio legis para convertirse en lex, momento en el que pasan a formar parte del sistema positivo de las normas, surgiendo de aquí la concepción de los principios pospositivistas, según la cual los principios son normas y estas comprenden igualmente los principios y reglas (Bonavides, 2013: 281). 
En esta última tercera fase de los principios, las referidas normas se pueden definir en base a dos aspectos:

- son reconocidas a partir de los textos que sintetizan valores fundamentales del sistema de normas y sirven para estructurarlo; son mandamientos nucleares del sistema de normas, fundamentando la existencia de reglas en este sistema; $y$,

- son normas que establecen que se debe alcanzar un fin en la mayor medida posible.

No es científicamente correcto optar por uno de los aspectos y despreciar el otro. Sin el desarrollo del concepto de normas estructurales no hay sistema jurídico. Sin el concepto de norma como un deber ser, aplicado en la mayor medida posible, no hay ponderación, lo que puede crear una barrera a la interpretación efectiva del derecho (Martins y Pires, 2012: 118).

En su «teoría de los derechos fundamentales», Robert Alexy afirma que la más importante de las diferencias teórico-estructurales normativas es aquella relacionada con las reglas y principios, y es notoria la inexistencia de una distinción precisa entre estas dos especies de normas y una utilización sistemática de esta distinción. Las reglas y los principios son especies de normas, porque ambos dicen lo que debe ser, pueden formularse mediante expresiones básicas del deber, del permiso y de la prohibición. Principios son, tanto cuanto las reglas, razones del deber ser, aunque de especies muy diferentes (Alexy, 2012: 85).

Existen diversos criterios para distinguir los principios de las reglas. El más utilizado es el de la generalidad, o sea, los principios son normas con un grado de generalidad relativamente alto, mientras que las reglas tienen un grado de generalidad relativamente bajo. Otros criterios discutidos para la distinción son: la determinación de los casos de aplicación; la forma de su surgimiento; el carácter explícito de su contenido axiológico; la referencia a la idea de derecho o a una ley jurídica suprema; y la importancia para el orden jurídico (Alexy, 2012: 87-88).

La existencia de varios criterios para la distinción entre principios y reglas desencadena tres tesis sobre la posibilidad de concretar esta diferencia:

- no es posible concretar la diferencia frente a la vaguedad y la diversidad existente;

- puede ser posible, pero solamente en términos de grado, o sea, en lo que respecta a su aspecto de generalidad; $y$,

- la distinción es totalmente posible teniendo en cuenta la existencia de una diferencia cualitativa. Esta última tesis es la más adecuada, según Robert Alexy (2012: 89).

Respecto a la diferencia cualitativa, Alexy afirma, a partir de una primera disertación no exhaustiva sobre el tema, que las reglas son satisfechas o no satisfechas, es decir, aplicadas en la forma del todo o nada. Cumplidos los requisitos para la aplicación de la regla, esta debe incidir en el caso concreto, por subsunción. El conflicto entre las reglas se resuelve de dos maneras: 
- mediante la creación de una cláusula de excepción para una de las reglas, aplicándose la regla opuesta; $y$,

- por la declaración de nulidad de la regla de jerarquía inferior, en caso de conflicto entre dos reglas de jerarquía distinta. ${ }^{7}$

Los principios son tratados como mandamientos de optimización, ya que pueden satisfacerse en grados variados y por el hecho de que la medida debida de su satisfacción no depende solo de las posibilidades jurídicas, sino también de las posibilidades fácticas. Esta limitación existe porque, en algunos casos, algunos principios entran en vía de colisionar con otros.

La forma de resolver el conflicto entre principios es la ponderación, que no está hecha en abstracto, sino que debe tener en consideración las peculiaridades del caso concreto (Alexy, 2012: 90-91). Constatada, en el caso concreto, la colisión entre dos principios que amparan intereses opuestos, uno de ellos debe ceder.

Afirma Luís Alberto Barroso:

Cuando un derecho fundamental entra en la vía de colisión con otro, el juez encargado de resolver la disputa estará delante de un conflicto normativo al que tendrá que dar solución. Teniendo en cuenta la cuestión de la supremacía de las normas constitucionales y de su unidad, no se puede ignorar uno de los derechos. El juez, por tanto, tendrá que adoptar una fórmula de convivencia entre los derechos en conflicto mediante compresión recíproca. La ley también podrá formular restricciones a los derechos afectados e incluso fijar parámetros para solucionar la colisión entre los derechos. Sin embargo, su papel en este campo es más limitado, ya que no es posible establecer en abstracto y con carácter general una prioridad rígida entre derechos que tienen una misma jerarquía (Barroso, 2003: 109-141).

Esto no significa la invalidación del principio relegado en el caso, sino tan solo la prevalencia momentánea del otro principio en colisión en aquella situación. ${ }^{8}$ De los es-

7. «Como ejemplo de implementación de la cláusula de excepción tenemos lo siguiente: está prohibido salir de la clase antes de que toque la campana. Sin embargo, existe otra regla que permite salir de la clase en cualquier horario, siempre que suene la alarma de incendios. Verificado el incendio, se introduce una cláusula de excepción en relación con la primera regla. Esta cláusula de excepción es también una norma de ordenamiento jurídico. Tratando el ejemplo de la invalidación de una regla, tenemos el siguiente caso: una ley del Estado de Baden prohibía la apertura de los establecimientos comerciales los miércoles, después de las $13 \mathrm{~h}$. La legislación alemana permitía el trabajo durante todos los días hábiles, de las $7 \mathrm{~h}$ hasta las 19h. Quedó declarada la nulidad de la norma de derecho estatal, por contrariar la regla federal» (Alexy: 2012: 92-93).

8. «Se puede citar, como ejemplo, la siguiente situación; un acusado de un crimen no pretende comparecer a la audiencia de instrucción por la posibilidad real de que en esa situación sufra un infarto. Por otro lado, el Estado tiene el interés de garantizar a la adecuada aplicación del derecho penal y el derecho procesal penal. Entran en conflicto, en esta situación, dos principios: dignidad de la persona y respeto al estado de derecho. En el caso concreto, prevalece el principio de dignidad de la persona, ya que se puso en jaque un derecho fundamental. Un punto importante es el hecho de que el principio de Estado de Derecho 
tudios de profundización que la doctrina realiza sobre los principios, se puede concluir que se diferencian de los valores en un único aspecto: los primeros (principios) tienen carácter axiológico y, los últimos (valores), carácter deóntico. Todo principio tiene un valor relativo, que es susceptible de ponderación (Martins y Pires, 2012: 35-37).

Cuando el intérprete se encuentra delante de una situación reveladora de principios en colisión y establece el método de ponderación, teniendo en cuenta la respuesta más adecuada al caso concreto, debe tener en cuenta el principio de proporcionalidad (Guerra Filho, 2001: 153), ${ }^{9}$ que se aplicará después de recorrer las tres etapas sucesivas y necesarias. La primera se refiere a la verificación de la adecuación, fase en la que se verifica si el medio es necesario para la consecución del fin; después, si la medida se considera inadecuada y desproporcional; y, posteriormente, viene la constatación de su necesidad. Desde esta perspectiva, se constata la existencia (o no) de otro modelo que - siendo tan eficaz para concretar el valor destacado-, dificulte de manera menos intensa la concreción de los demás valores. Existiendo, el medio se considera innecesario y, por tanto, desproporcional. Y, finalmente, se realiza la evaluación de la existencia de la proporcionalidad en sentido estricto, ocasión en la que se apura el peso de los valores incidentes y se decide si otro valor impide (o no) la concreción pretendida (Martin y Pires, 2012: 75).

El resultado de la técnica de ponderación de los principios, que tiene en consideración la precedencia general (carga axiológica del valor positivado), los matices del caso concreto y el principio de proporcionalidad, culmina en la creación de una regla. $\mathrm{O}$ sea, el principio que resulta del procedimiento de ponderación no incide de modo deductivo en la situación de hecho, lo que incide es una especie de regla creada a partir de la técnica de la ponderación. Y esa regla puede ser aplicada por deducción en casos similares, siempre que las condiciones jurídicas (los mismos principios) y fácticas (situación concreta) sean compatibles con el nuevo caso que requiere una decisión (Alexy, 2012: 98-99).

El concepto sobre principios está lejos de ser pacificado por la doctrina, lo que también puede decirse respecto a la teoría más adecuada a la aplicación de estas normas. Sin embargo, para el presente estudio basta la teoría general esbozada hasta ahora, ya que se puede considerar suficiente como premisa al desarrollo de una posible respuesta al conflicto entre el principio de libertad de expresión y el de intimidad.

podría prevalecer sobre el principio de la dignidad de la persona humana en otra situación, o sea, la atribución de mayor peso a un principio u otro no se puede concretar en abstracto, sino solamente en el caso concreto» (Alexy, 2012: 96-97).

9. Respecto a la discusión doctrinaria sobre el hecho de que la proporcionalidad se un principio, regla o regla de interpretación, se adopta aquí el concepto de Willis Santiago Guerra Filho, según el cual: «La conclusión a la que se quiere llegar, entonces, es que el principio máximo buscado, que, por su especialidad, tanto se diferencia de los demás, se encuentra expreso en la ya mencionada "máxima de proporcionalidad". La imposición en la contienda es la que se realiza a través del Derecho, concretamente y cada vez mejor, lo que es jurídica y fácticamente posible, para obtener la optimización en la adecuación de la norma, con su deber ser de entidad ideal, a la realidad existencial humana». 


\section{El derecho a la intimidad, a la honra y a la vida privada}

El derecho a la libertad de expresión y a la información son fundamentales y están en la Constitución de Brasil:

Artículo 5. Todos son iguales ante la ley, sin distinción de cualquier naturaliza, garantizándose a los brasileños y a los extranjeros residentes en el País la inviolabilidad del derecho a la vida, a la libertad, a la igualdad, a la seguridad y a la prioridad, en los siguientes términos: [...]

IV. Es libre la manifestación del pensamiento, quedando prohibido el anonimato;

VIII. Nadie será privado de derechos por motivo de creencia religiosa o de convicción filosófica o política, salvo si las invocara para eximirse de obligación legal impuesta a todos y rehusase cumplir la prestación alternativa, fijada por ley;

IX. Es libre la expresión de la actividad intelectual, artística, científica y de comunicación, sin necesidad de censura o licencia. [...]

Artículo 220. La manifestación del pensamiento, la creación, la expresión y la formación, bajo cualquier proceso o vehículo no sufrirán ninguna restricción observándose los dispuesto en esta Constitución.

2. ${ }^{\circ}$ Está prohibida toda censura de naturaleza política, ideológica y artística.

En este contexto, se puede decir que las libertades de expresión y de información tienen valor fundamental en el sistema constitucional, principalmente teniendo como marco el final de los años de la dictadura. Es irremediable, sin embargo, aclarar que la inviolabilidad de la intimidad y de la vida privada tiene igual fundamento constitucional y derivan directamente de la dignidad humana.

La expresión «derechos fundamentales» no significa que la esfera privada se contraponga a la actividad pública, como simple limitación al Estado o autolimitación de este; pero sí una limitación impuesta por la soberanía popular de los poderes constituidos del Estado que de ella dependen. Al situar su fuente en la soberanía popular, implícitamente está definiendo su historicidad, que es precisamente lo que enriquece su contenido y les pone en consonancia con las relaciones económicas y sociales de cada momento histórico. La Constitución, al introducirlos dentro del ámbito que lo hizo, tradujo un desdoblamiento necesario de la concepción de Estado recogida en el artículo 1: «Estado Democrático de Derecho». El hecho de que el derecho positivo no les reconoce toda la dimensión y amplitud popular en el ordenamiento, no les quita esa perspectiva, por tanto, según lo comentado anteriormente, en la expresión también se contienen principios que resumen una concepción del mundo que orienta e informa la lucha popular por la conquista efectiva d estos derechos.

Son derechos constitucionales en la medida que se introducen en el texto de una Constitución o, igualmente, constan de simple declaración de solemnidad establecida por el poder constituyente. Son derechos que nacen y se fundamentan, por lo tanto, en el principio de la soberanía popular.

La libertad de expresión es el derecho que todo y cualquier individuo tiene de manifestar su pensamiento, opinión, actividad intelectual, artística, científica y de comuni- 
cación, sin cesura, como recoge el artículo 5 de la Constitución Federal. Es un derecho de la personalidad, inalienable, irrenunciable, intrasmisible e irrevocable, esencial para concretar el principio de dignidad humana. Es una forma de proteger a la sociedad de la opresión. Es el elemento fundamental de las sociedades democráticas, que tiene en la igualdad y en la libertad sus pilares.

Merece hacer una excepción referente al artículo 20 del Código Civil por razones de interés público, como el conocimiento de la historia, para llegar a las biografías y obras que tengan en cuenta las personas notorias, cuya trayectoria de vida sea relevante para el conocimiento, en lo que se refiere a los hechos, pasajes y episodios, lejos de la mera curiosidad en detalles de la vida privada, intimidad o secreto que no tengan pertinencia con datos importantes para la historia. En este interés diferenciado se incluyen no solo los personajes de la evolución política del país, sino también los que destacaron por su excelencia en las artes, los deportes, en el ejercicio de sus profesiones o en otras actividades.

El derecho de expresión deriva de actos propios. Mientras el derecho de informar puede derivar de actos $\mathrm{u}$ hechos relacionados con terceros, el acto de informar, normalmente, es solo divulgativo, no comprendiendo una acción propiamente material directa, sino formal. Teniendo ambos sus limitaciones.

Para José Alfonso da Silva:

Libertad de información periodística: Es en esta que se concreta la libertad de información, que asume características modernas, superadoras de la vieja libertad de prensa. En ella se concentra la libertad de informar, y es ella o a través de ella que se realiza el derecho colectivo a la información, o sea, la libertad de ser informado. Por esto es que el orden jurídico la confiere un régimen específico que le garantiza su actuación y la protege de los abusos. A propósito de la libertad de prensa cabe recordar las palabras de Marx: "la prensa libre es la mirada omnipotente del pueblo, la confianza personalizada del pueblo en el mismo, el vínculo articulado que une al individuo con el Estado y con el mundo, la cultura incorporada que transforma las luchas materiales en luchas intelectuales, e idealiza sus formas brutas. Es la franca confesión del pueblo así mismo, y sabemos que el poder de la confesión es la redención. La prensa libre es el espejo intelectual, en el cual el pueblo se mira, y la visión de sí mismo es la primera confesión de la sabiduría" (Silva, 2009b: 239).

Existen fundamentos en la Constitución que realzan el interés público, como la libertad de expresión consagrada como derecho y garantía fundamental en el apartado 9 del artículo 5, pero no ilimitada, considerando otros derechos implicados entre los cuales los expresamente mencionados en el artículo 220. No siempre es fácil resolver el conflicto entre dos derechos consagrados. La colisión de derecho de tal naturaleza debe ponderarse según el principio de la proporcionalidad.

Paulo Gustavo Gonet Branco esclarece que la libertad de expresión tutela "al menos en cuanto no haya colisión con otros derechos fundamentales y con otros valores constitucionales establecidos, toda la opinión, convicción, comentario, evaluación o juicio 
sobre cualquier persona, que afecte un tema e interés público" (Mendes y Branco, 2011: 299).

El autor analiza los límites de la libertad de expresión, previsto tanto por el legislador como por la colisión de este derecho con otros que considera del mismo estatus. Entre estos, las muchas excepciones realizadas de forma expresa en el artículo 220. Invoca, todavía, el test de razonabilidad que debe atender a los criterios que son la base del principio de proporcionalidad.

Se debe enfatizar que el veto a la censura no significa la inexistencia de sanciones, citando la opinión de Konrad Hesse, al respecto de Ley Fundamental alemana; hipótesis que también puede aplicarse, según pensamos, al derecho brasileño.

Respecto a la divulgación de noticias pondera que no todas tienen interés público; que el denominado «hombre público» no renuncia, necesariamente, a su privacidad y que no basta la veracidad de la noticia sobre alguien para que se legitime su divulgación.

La libertad de expresión no es ilimitada, según ya decidió el Supremo Tribunal Federal en el Habeas Corpus 82242-2/RS, del cual fue relator el ministro Moreira Alves, juzgado en 2003 (Sentencia del Pleno del Supremo Tribunal Federal de Brasil Habeas Corpus 82242-2/RS, rol 2144-3, 2003)..$^{10}$

Por lo tanto, aunque la Constitución Federal en vigor prohíba cualquier forma de censura, el ciudadano y especialmente los vehículos de comunicación social, en el ejercicio de la libertad de expresión e información, no deben olvidar los derechos de los otros ciudadanos o los derechos de la colectividad, bajo pena de caer en abuso de la libertad de expresión o información. Punto que refuerza el derecho a la intimidad, el derecho de resguardarse de los sentidos ajenos.

Todos tienen el derecho de mantenerse en reserva, de velar por su intimidad, de no dejar que invadan su vida privada, pero con límites: el interés del agente en revelar la intimidad y el consentimiento con la revelación de la intimidad. La libertad es la base del derecho a de proteger la intimidad, la libertad de hacer o no hacer. El derecho de proteger es un derecho derivado de la libertad que es un derecho innato de la personalidad.

Las limitaciones a la intimidad y las limitaciones a la renuncia a la intimidad son, por consiguiente, concernientes a la libertad misma: todos deben respetar un mínimo de intimidad y al mismo tiempo ninguno puede ser privado de ese mínimo de intimidad. En la biografía del hombre vivo, el biógrafo no puede ir más allá de lo que acabaría siendo una injuria difamación, ni más allá de lo indispensable, o científica o literariamente provechoso, la exposición de los hechos de vida y su explicación. Es preciso tener siempre en vista el interés más relevante, si lo hay; el valor científico, artístico, literario.

El derecho a la inviolabilidad de la correspondencia cerrada, aunque no resulte de la confidencialidad, existe como derecho absoluto. El escrito, carta u obra, si está en el so-

10. Emanada en 17 de septiembre de 2003 y publicada en el Diário da Justiça Eletrônico el 19 de marzo de 2004 . 
bre, todavía no se separó suficientemente de la persona o no se concibió como separable, de modo que se concibe como irradiación de la personalidad. La correspondencia como carta que tenga valor científico, artístico, literario o industrial conlleva el derecho de autor: vinculación del escrito con quien lo escribió (autenticidad, proyección de los derechos a la identidad personal, derecho de la personalidad). El derecho de la personalidad, respecto a la inviolabilidad de la correspondencia, es la libertad de no emitir el pensamiento a todos o más allá de ciertas personas. De esa libertad nace el derecho a la inviolabilidad de la correspondencia.

El derecho al secreto cesa si falta, en el soporte fáctico o del hecho-acto jurídico del secreto, la negación de la emisión o publicación. Es un derecho de la personalidad nato, cuando se ejerce a la libertad de hacer o no hacer, o de emitir o no un pensamiento, a la intimidad, o el secreto que resulta del acto-hecho del ejercicio de tales libertades, es un objeto de derecho a la intimidad o al secreto. Cesa también cuando otro derecho más alto está frente a él, como, por ejemplo, si fuera medio de prueba.

La violación de la correspondencia que no sea para su publicación afecta solo al derecho al secreto. Sobre la disponibilidad del derecho al secreto se ha discutido mucho, en razón del consentimiento para la exposición o publicación. Sin embargo, no puede existir disponibilidad o renuncia a este derecho por ser un derecho de personalidad.

El valor positivado de la intimidad garantiza al individuo protección contra la indiscreción ajena en los asuntos privados que solo a él le interesa (Farías, 2000: 140). Referido al principio normativo impide que las personas en general e incluso las personalidades públicas, como, por ejemplo, nuestros gobernantes, vean determinados hechos de su intimidad aireados, siempre que las referidas informaciones no tengan conexión con asuntos de interés público. El objetivo a alcanzar es el de la preservación de la paz íntima de las personas (Farías, 2000: 143).

\section{Casos emblemáticos y discusión actual}

Con esta línea de razonamiento, específicamente sobre la posibilidad del olvido, no podemos dejar de comentar el caso Lebach. De forma sintética, este caso tuvo lugar en la República Federal Alemana en 1969. Cuatro soldados del ejército de la RFA fueron brutalmente asesinados, $y$ un quinto gravemente herido, cuando se realizaba un robo en un almacén de armamento y municiones. Los dos principales acusados del crimen fueron condenados a prisión perpetua, y un tercero, que participó en la planificación, fue condenado a seis años de reclusión (Kommers, 1997: 416).

Cuatro años después del delito, una cadena de televisión local quiso realizar un documental. La reconstrucción, además de detallar el crimen, se centró en una supuesta relación homosexual entre los condenados, culminando con la exposición del nombre y la foto de estos. El caso adquirió relevancia cuando el tercer acusado, ya habiendo cumplido más de la mitad de su condena, buscó la tutela del Estado alemán para garantizar su derecho al olvido, en vista del proceso de resocialización del delincuente, no pudiendo el condenado ser nuevamente juzgado, no por jueces competentes, pero 
si por la opinión pública. En este caso, se reconoció la prevalencia del derecho a la personalidad.

En la misma línea del ejemplo comentado, también en Alemania, interesa destacar el caso de Wolfgang Werlé, en el cual, brevemente, se analizó su afán de excluir cualquier información relativa al autor en la web de Wikipedia, teniendo como referencia la decisión tomada en el caso Lebach. La pretensión se relacionaba con el hecho de que el autor, en la década de los noventa, fue condenado por el homicidio de un famoso actor alemán. El hecho tuvo una gran repercusión nacional y fue posteriormente relatado en las páginas de Wikipedia.

En la fundamentación, se demostraba que en 2009, año de interposición de la demanda, el autor ya se encontraba en libertad, habiendo cumplido íntegramente su pena, por lo que, entonces, pretendía garantizar su derecho de resocialización. Inspirado en la decisión del caso Lebach, el autor se dirigió al Tribunal de Hamburgo para garantizar el derecho a la privacidad. La Corte acogió la tesis del autor mediante un acuerdo, por lo cual la web debía retirar el nombre del autor de todas sus publicaciones existentes, bajo pena de multa de $€ 5.100,00$ (cinco mil cien euros) por violación comprobada. Haciendo efectivo, con esto, una vez más, en la jurisprudencia alemana, la posibilidad del olvido.

Finalmente, el 13 de mayo de 2014, el Tribunal de Justicia de la Unión Europea (UE) pudo finalmente abordar el tema de la posibilidad del reconocimiento del derecho al olvido en internet, mediante el análisis del caso español Mario Costeja vs. Google. Tras el reconocimiento de la posibilidad de exclusión de datos equivocados de la indexación del sistema de búsqueda de Google Search por parte de la Agencia de Protección de Datos Personales de España, se remitió al Tribunal de Justicia de la UE para analizar los recursos manejados por Google. Allí, después de la opinión favorable del Abogado General de la UE, la Corte decidió que cabía el derecho al olvido siempre que la indexación tuviera algún prejuicio para la persona indexada.

En Brasil, el derecho al olvido ya se afrontó en dos oportunidades por el Tribunal Superior de Justicia, en dos juicios, en el 2013, el Recurso Especial 1.334.097 ${ }^{11}$ y el Recurso Especial 1.335.153. ${ }^{12}$

Del análisis de los dos acuerdos mencionados se puede concluir que el Tribunal Superior de Justicia reconoce la posibilidad jurídica del derecho al olvido, alineándose con la jurisprudencia extranjera, principalmente en Europa y en los Estados Unidos.

El fundamento mayor del derecho al olvido, en el primer caso, es la dignidad de la persona humana (Constitución de la República Federativa del Brasil, artículo 1, número 3), materializada en los derechos de la personalidad, y concretados en la regeneración y resocialización de los titulares. Además, se admite que el conflicto se da «entre

11. Redactada por el relator ministro Luis Felipe Salomão, emanada el 28 de mayo de 2013 y publicada en el Diário da Justiça Eletrônico el 10 de septiembre de 2013.

12. Redactada por el relator ministro Luis Felipe Salomão, emanada el 24 de junio de 2014 y publicada en el Diário da Justiça Eletrônico el 1 de agosto de 2014. 
el legítimo interés del 'querer ocultarse' y, por otro lado, el también legítimo interés de 'revelarse'» (Recurso Especial del Tribunal Supremo de Justicia del Brasil 1.334.097, 2013: 23). Se recurre al Enunciado 531 de las VI Jornadas de Derecho Civil promovida por el CJF/Tribunal Superior de Justicia (Recurso Especial del Tribunal Supremo de Justicia del Brasil 1.334.097, 2013: 24-25), que destaca los razonamientos de Paulo José da Costa Júnior sobre el derecho a dejarle en paz o el derecho a estar solo (right to be alone) (Costa Júnior, 2007) (Recurso Especial del Tribunal Supremo de Justicia del Brasil 1.334.097, 2013: 28-29) y se ajusta en la afirmación de François Ost (2005: 159) de que el reconocimiento jurisprudencial del derecho al olvido surge como una de las múltiples facetas del derecho al respeto a la vida privada (Recurso Especial del Tribunal Supremo de Justicia del Brasil 1.334.097, 2013: 55).

La contemporaneidad/actualidad resulta también decisiva para definir la mediación entre la prevalencia del derecho a informar o del derecho al olvido. Debe tenerse en cuenta la libertad de prensa y la relevancia de la historicidad de la noticia, pero tratar nuevamente de forma continua, sin restricciones e indefinidamente en el tiempo un delito y a las personas en este implicadas puede significar un abuso contra la dignidad de la persona humana.

Se destaca que la titularidad del derecho al olvido es extensible a todos los implicados en el hecho. En los casos tratados, que aludían a delitos, se borraron a los titulares: condenados, absueltos, víctimas y familiares.

Se observa, en este análisis, que la principal fundamentación normativa es el recurso a la dignidad de la persona humana, positivado en la Constitución, de la cual derivan los derechos de la personalidad y la "presunción legal y constitucional de rehabilitación de la persona humana» (Recurso Especial del Tribunal Supremo de Justicia del Brasil 1.334.097, 2013: 47; Recurso Especial del Tribunal Supremo de Justicia del Brasil 1.335.153, 2014: 39).

En Chile, en una resolución reciente, unánime y sin precedente en el país, la Corte Suprema de Chile afirmó que el derecho a la información se sobrepone al derecho al olvido. La sentencia se dictó a favor del Centro de Investigación Periodística, CIPERChile, después de la solicitud de un médico de eliminar en la web del Centro un reportaje sobre una mala praxis médica.

En la acción, el ginecólogo Víctor Valverde pidió que CIPER eliminase de sus registros un informe sobre sus prácticas con el uso del Mysotrol, argumentando que eso afectó su derecho a la honra. Sin embargo, la Corte Suprema no lo aprobó, ratificando la decisión de la Corte de Apelaciones de Santiago, y observó que la información es relevante pues se probó que es de interés público. Esta es una decisión relevante, precisamente cuando en el mundo se está debatiendo el «derecho a ser olvidado», que busca eliminar artículos en internet, lo que contrasta con el derecho de ser informado.

El caso más reciente y que probablemente generará mayor repercusión mundial es el de Google. La empresa busca no querer verse forzada a aplicar el derecho al olvido que está en vigor en la UE, fuera del bloque, y esto se decidirá en los próximos meses por 
el Tribunal de Justicia de la UE. La orden de la autoridad reguladora de la privacidad en Francia que determinó que el principio europeo de derecho al olvido sea aplicado en todo el mundo se dio hace tres años y desde entonces Google y otros buscadores de internet intentan revertir la situación alegando que existe un riesgo real de reducir la libertad de expresión a su mínimo denominador común, en toda Europa y en el mundo.

\section{Conclusión}

A través del análisis realizado, se constató que el derecho al olvido es un derecho inherente de la personalidad, ya que atraviesa el rol de la privacidad, de la honra y de la imagen. Frente a esto, se observó cómo este instituto se comporta cuando entra en conflicto con los derechos de la libertad de prensa y de expresión, derechos constitucionales conquistados y muy proclamados.

Se afirma que sin información no existe la libre opinión y sin esta no existe la democracia. Sin embargo, la democracia no será sacudida, como no lo está siendo y nunca lo fue, por culpa del derecho al olvido. Son los intereses económicos de proveedores e indexación, los que sí sufrirán las consecuencias directas a partir de las decisiones de las cortes y, en un futuro, de la regulación legal de este derecho.

Si el artículo 5 de la Constitución Federal garantiza a todos el derecho a la libre manifestación del pensamiento, a la libre expresión de la actividad intelectual, artística, científica y de comunicación, independientemente de la censura o el permiso, y el derecho a la información, no se puede olvidar que el propio artículo garantiza, en su apartado 10, que son inviolables la intimidad, la vida privada, la honra y la imagen de las personas, garantizado el derecho a la indemnización por el daño material o moral derivado de su violación.

No obstante, no existe una regla o principio absoluto. La inviolabilidad de la intimidad y de la vida privada no debe prevalecer para ocultar ilegalidades. Un ejemplo de esto es que el derecho a la libre manifestación de pensamiento no es ilimitado, después de todo, la apología del delito, en Brasil, está tipificada por el Código Penal.

Con el estudio, se analizó la posibilidad fáctica de que el derecho al olvido sea visto como un derecho fundamental, ya que la dignidad de la persona humana tiene que ver con esta acepción, cuando se defiende el derecho del individuo de no querer ser recordado por un acontecimiento desagradable, del cual ya se ha redimido.

Finalmente, se observa que tanto los tribunales superiores brasileños como tribunales extranjeros son extremadamente parsimoniosos frente a esta reflexión, prefiriendo examinar caso a caso, sopesando los derechos en cuestión, de manera que no se tome ninguna decisión que perjudique, además del individuo per se, a la colectividad.

\section{Referencias}

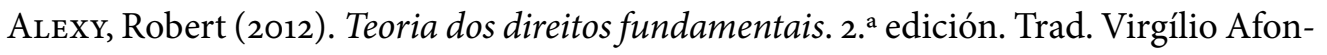
so da Silva. São Paulo: Malheiros. 
Arendt, Hannah (2010). A condição humana. 11. ${ }^{a}$ edición. Rio de Janeiro: Forense Universitária.

BARroso, Luís Roberto (2003). “Colisão entre liberdade de expressão e direitos da personalidade. Critérios de ponderação. Interpretação constitucionalmente adequado do Código Civil e da Lei de Imprensa”. Revista Trimestral de Direito Civil, 16: 59-102.

Bastos, Celso Seixas Ribeiro (2010). Comentários à Constituição do Brasil. 22. ${ }^{\mathrm{a}}$ edición. São Paulo: Malheiros.

Bitencourt, Cezar Roberto (2014). Tratado de Direito Penal. Tomo 2. 14. ${ }^{\text {a }}$ edición. São Paulo: Saraiva.

Bittar, Carlos Alberto (2001). Os direitos da personalidade. $5 .^{\text {a }}$ edición. Rio de Janeiro: Forense Universitária.

Bonavides, Paulo (2013). Curso de direito constitucional. 28. ${ }^{a}$ edición. São Paulo: Malheiros.

Costa Júnior, Paulo José da (2007). O direito de estar só: tutela penal da intimidade. São Paulo: Ed. RT.

Cupis, Adriano de (1950). I diritti della personalità. Milán: Giuffrè.

DonedA, Danilo (2006). Da privacidade à proteção dos dados pessoais. Rio de Janeiro: Renovar.

FARÍAs, Edilsom Pereira de (200o). Colisão de direitos. A honra, a intimidade, a vida privada e a imagem versus a liberdade de expressão e informação. 2. ${ }^{\text {a }}$ edición. Porto Alegre: Sérgio Antônio Fabris.

FlorÊnCIO, Juliana Abrusio (2011). “Direito ao esquecimento na Internet." En Ana Flávia Messa, Nuncio Theophilo Neto y Roque Theophilo Junior (coordinadores), Sustentabilidade ambiental e os novos desafios na era digital. São Paulo: Saraiva.

Guerra Filho, Wilis Santiago (2001). Teoria da ciência jurídica. São Paulo, Saraiva.

Hobbes, Thomas (2008). Leviatã. Trad. João Paulo Monteiro e Maria Beatriz Nizza da Silva. 2. edición. São Paulo: Martins Fontes.

Kommers, Donald (1997). The Constitutional Jurisprudence of the Federal Republic of Germany. Durham: Duke University Press.

Martins, Ricardo Marcondes y Luis Manuel Fonseca Pires (2012). Um diálogo sobre a justiça: a justiça arquetípica e a justiça deôntica. Belo Horizonte: Fórum.

MAYER-Schönberger, Viktor (2009). Delete: The virtue of forgetting in the digital age. Princeton: Princeton University Press.

Mendes, Gilmar Ferreira y Paulo Gustavo Gonet Branco (2011). Curso de direito cons-

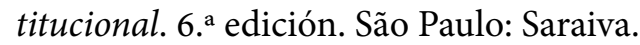

Murillo De la Cueva, Pablo Lucas (1990). El derecho a la autodeterminación informativa. Madrid: Tecnos.

NADER, Paulo (2012). Filosofia do direito. 21. ${ }^{\text {a }}$ edición. Rio de Janeiro: Forense.

Ost, François (2005). O tempo do direito. Trad. Élcio Fernandes. Baru: Edusc.

Pontes de Miranda, Francisco Cavalcanti (2012). Tratado de direito privado. Actualizado por: Judith Martins-Costa, Jorge Cesa Ferreira da Silva e Gustavo Haical. Sao Paulo: Revista dos Tribunais. 
RoDotÀ, Stefano (2008). A vida na sociedade de vigilância: a privacidade hoje. Rio de Janeiro: Renovar.

Silva, José Afonso da (2009a). Comentário contextual à Constituição - $6^{\circ}$ Edición. São Paulo: Malheiros.

-. (2009b) Curso de Direito Constitucional Positivo. $32^{\circ}$ Edición revisada y actualizada. São Paulo: Malheiros.

Schopenhauer, Arthur von (2002). Aforismos para a sabedoria de vida. São Paulo: Martins Fontes.

Szaniawski, Elimar (1993). Direitos de personalidade e sua tutela. São Paulo: Revista dos Tribunais.

Tepedino, Gustavo, Heloisa Barboza y Maria Celina Bodin de Moraes (2007). Código Civil interpretado conforme a Constituição da República. Volumen 1. 2. ${ }^{a}$ edición. Rio de Janeiro: Renovar.

WARren, Samuel y Louis Brandeis (1890). «The right to privacy». Harvard Law Review, 4 (5): 193-220. Disponible en http://bit.ly/2Rjfggm.

VAsConCEllos, Pedro País (1999). «Proteção de dados pessoais e direito à privacidade». Direito da Sociedade da Informação, I.

\section{Sobre la autora}

Thamiris Schiavinoto Guimarães es abogada y Graduada en Derecho de la Faculdade de Direito de São Bernardo do Campo (FDSBC) de Brasil (2015). Su correo electrónico es thamiris.schiavinoto@gmail.com. (D) https://orcid.org/oooo-0002-5015-6375. 
